\title{
The Politics of Modern Honor
}

Modern honor appears to be distinguished by two contradictory impulses, a neglect or even disdain of honor, and an ambition to elevate and promote it as dignity, self-esteem and recognition. The article argues that these tensions can be traced to a foundational difference regarding the political importance of the passion of honor, evident in the seminal and contending formulations by Machiavelli and Hobbes. In recovering and articulating the bases of these competing modern conceptions of honor and tracing the influence of their divergent trajectories, the article seeks to show the importance of honor for understanding contemporary politics.

Keywords: honor, recognition, dignity, modernity, Machiavelli, Hobbes

Professor Haig Patapan

Director, Centre for Governance and Public Policy

Griffith University, Australia

h.patapan@griffith.edu.au 


\section{The Politics of Modern Honor}

It seems quaint, even old fashioned to talk of honor. With its unjust hierarchies, pretentious airs and cold cruelties honor seems safely behind us now. When it does intrude into our lives, for example as 'honor killings', it is only to confirm its atavistic irrationality, violence and dangerousness. ${ }^{1}$ Perhaps it is true, that as modern men and women we have freed ourselves from the 'mystifications of honor'. ${ }^{2}$ From this perspective, we need not concern ourselves with honor because politics can be understood within the scientifically parsimonious conceptual framework of interest and power. ${ }^{3}$ Yet even a cursory glance shows that honor and the passions more generally, have much to tell us about modern politics. It is not just our seemingly voracious appetite for celebrity and fame that can influentially shape politics. ${ }^{4}$ It is above all the significance of self-esteem and self-respect, and the moral demands to recognize the dignity of others - seemingly honor in new clothes - that confirms the continuing salience and centrality of modern honor for contemporary politics.

Modern honor therefore appears to be distinguished by two contradictory impulses - a neglect or even disdain of honor, and a continuing ambition to elevate, celebrate and promote it as dignity, self-esteem and recognition. This puzzle about divergent trajectories of modern honor is clearly an important starting point for understanding the meaning of honor and its role in contemporary politics. Yet in examining this question more closely what emerges is a more profound debate in modernity regarding honor's significance, its tractability, and importantly, how different views of honor have led to radically divergent conceptions of the best form of political ordering. Our question concerning honor is therefore important not only for understanding modern honor, but for understanding modernity itself.

In this article I argue that modernity inaugurates a decisive break from classical and pious conceptions of honor, an innovative perspective that continues to shape our 
contemporary conceptions of honor, and the political institutions that emerge from them. Though starting with common presuppositions in repudiating classical and pious conceptions, especially in the need to deploy passions to counter passions and relying on institutions to solve the problem of political instability, modern honor is characterized by two divergent views, evident in the seminal and contending articulations of honor by Machiavelli and Hobbes. Machiavelli seeks to rehabilitate honor from the abject place it occupied in pious thought, but does so not by recovering the classical conception of magnanimity, but on modern terms, seeing in honor the only passion that can reconcile the demands of the gloryseeking few and the honor loving many to found a modern republicanism. Hobbes, though adopting many of Machiavelli's principles, repudiates his approach, seeing pride as the most dangerous political passion. His entire project is to master the 'children of pride', and thereby found a politics that has room only for the calculating fearful who abjure the chimeric charms of glory for individual rights, peace and prosperity. Though the Hobbesian view, subsequently altered and moderated has predominated, the Machiavellian perspective persists in modernity, presenting a continuing challenge to the Hobbesian disdain for pride. The overarching effect of both the Machiavellian and Hobbesian approaches to honor is to deny its efficacy altogether, or to depreciate or truncate its range and meaning, by uncoupling it from excellence and virtue, by equalizing it or seeing it as inherently unpolitical.

To understand contemporary conceptions of honor we will therefore have to recover this core debate in modernity, delineating the basis of each alternative position while contrasting it with classical and pious understandings of honor. In the first part of the article I distinguish between honor as passion from those specific notions of what is honorable. This distinction provides the basis for examining the classical conception of honor, where I note the difference between its 'two faces' - honor as pre-eminence and honor as defense of a moral code or 'what is right'. I then turn to modern honor, starting with Machiavelli's conception of 
Gloria and how he sees it as the crucial mediating passion that can reconcile ambition with republican freedom. This discussion is contrasted with Hobbes's profound confrontation with Machiavelli, accepting Machiavelli’s major premises while repudiating the core aspect of Gloria as ‘vaine-glory', a form of madness. Having outlined these contrasting positions, I then note their continuing force their influence in subsequent seminal debates in modern political thought. I conclude by showing how our recovery of this debate helps explain the powerful yet contradictory and fragmentary ways contemporary political science takes up the concept of modern honor, evident in the idea of honor as prestige, the conceptions of honor as dignity and recognition, and finally, the transformative and transactional dichotomy that dominates leadership studies.

\section{Two Faces of Honor}

To understand modern honor it is necessary to distinguish two related but separate questions, namely, the question of What is honor?, which examines the passion of honor, and the question of What is honorable?, that is, the substance of 'codes of honor' (Appiah, 2010; French, 2003). The question 'What is honorable?' has been especially salient in sociological and anthropological studies that show how distinct historical and cultural legacies uniquely color and inflect what is considered honorable. ${ }^{5}$ These questions of what is honorable presume an understanding of what is honor. But the question of what is honor, and more specifically, whether there is a unique aspect to modern honor are not easily answered. The passion of honor with all its subtle expressions and shades of meaning ranging from glory and hubris, to pride, vanity and fame is an important theme in western thought. It is a central concern of the poets, as we see from the Iliad, where Homer celebrates the nobility and grandeur of Achilles who exchanged a long life for a glorious one, while forcing us to confront the grave political consequences of such heroism. But it is Socrates, in inaugurating 
political philosophy, who undertakes the first philosophical examination of the passion. The most comprehensive and detailed account of the honor is therefore first found above all in the Platonic dialogues. Though all the Platonic dialogues at least touch upon the nature of honor and its political implications, it is especially in the Republic, the Statesman and the Laws, as well as the Symposium, Phaedrus, and Phaedo that we discern the nature of the economy of the soul, with its reasoning, desiring and spirited parts, and the political implications of this tripartite psychology. ${ }^{6}$ At the risk of oversimplification, these Platonic dialogues suggest that the desire to be praised or admired, and alternatively to avoid censure and shame is a uniquely human passion. It is also fundamentally political, to the extent that it cannot be experienced or satisfied by oneself, requiring the opinion of others, evident from their statements or actions, or in anticipation and therefore imagination. What is specifically praised or blamed will of course differ, as we know from the extraordinary diversity of what is considered honorable or shameful. Yet the passion itself, the desire to be loved, praised or admired for doing the right thing and therefore for the virtues we possess is present in everyone, though its strength or vehemence will vary between individuals. It is especially evident in those admirable or honorable actions that defend and thereby reveal the good and noble, always requiring courage and sometimes sacrifice. We therefore praise and honor above all the patriot who is willing to give his life for his country. ${ }^{7}$ The willingness to sacrifice and in the extreme give up one's life to do the honorable and right thing can in most cases trace its source to the longing for immortality. The desire to be praised, admired and remembered even, or especially after we die, and therefore the need to recall and record for the future such noble actions, explains the importance of the arts for honor. ${ }^{8}$ This is the 'honestas' face of honor, showing how it can transform the entrenched and self-directed desires of material gain into noble ambition to benefit and protect those we love and admire. ${ }^{9}$ 
But there is a different 'face' of honor that also wants to be praised and not blamed, yet seeking satisfaction not in simply defending the good and noble, but in doing so in an outstanding way. In Plato's Republic this is the difference between honor loving (philotimia) and victory loving (philonikia). ${ }^{10}$ The impulse to be pre-eminent in virtue insinuates in the heart of the honor-lover a desire to excel and therefore seek victory over others in virtue. But in some cases the desire will turn against honor itself so that some will seek to redefine what is honorable to become pre-eminent, as Alexander did when he cut the Gordian knot rather than unravelling it. ${ }^{11}$ Others who have powerful, though frustrated, longing for pre-eminence will even seek to satisfy it by being outstanding in any way possible, even in vice or criminality. Herostratos is said to have burnt down the Temple of Artemis, one of the seven wonders of the ancient world, because he wanted to be famous (Borowitz, 2005).

This victory loving face of honor, in elevating pre-eminence, seemed to be a dangerous passion placing the individual above all. It was also considered dangerous because it seemed without limit and therefore shameless and sacrilegious, straining against all proper bounds. Thus honor as hubris explained the impulse towards tyranny or even more ambitiously, empire. Yet for Socrates a version of this passion was also the source for the turning around (periagoge) necessary for philosophical liberation (Republic, 518d). The education of honor is therefore a two-fold task for Socrates, employing the glory-seeking ambitions of a political founder such as Glaucon to direct him towards the philosophy, while accommodating the earnest honor loving desires of his brother Adeimantus to found the republic. Plato is not sanguine, however, regarding the efficacy of such education. Socrates may moderate, but does not turn around the exceptionally talented but ultimately un-philosophic Alcibiades. ${ }^{12}$ And we should not forget that even the citizens of the best city will ultimately require myths to ensure they are just. ${ }^{13}$ 


\section{Machiavelli and the Question of Gloria}

These general observations regarding what I would call the classical understanding of honor allow us to see the extent to which modern approaches represent new conceptions of glory and honor. In this section I will detail the pre-eminent and influential modern approach, most clearly articulated in Machiavelli’s conception of gloria.

The Abrahamic religions transformed the two faces of honor. Glory was God's alone, so all claims of pre-eminence that did not glorify God were the capital sin of 'stiff-necked' pride and vainglory (see Aquinas, Summa Theologica, II-II, Q. 132, art. 4). Made in the image of God, man reflected divine glory, yet in sinning Adam and Eve realized their nakedness and felt shame (Genesis, 1, pp. 26-27). Shame and humility were therefore the proper disposition for those who were no more than humus or 'dust'. ${ }^{14}$ Because of this transformation in the meaning of honor, 'our religion', according to Machiavelli, has 'rendered the world weak and given it prey to criminal men’:

the ancient religion did not beatify men if they were not full of worldly glory, as were captains of armies and princes of republics. Our religion has glorified humble and contemplative more than active men. It has then placed the highest good in humility, abjectness, and contempt of things human; the other placed it in greatness of spirit, strength of body, and all other things capable of making men strong (D II, 2, p. 131). ${ }^{15}$

Machiavelli will therefore attempt to rehabilitate worldly glory but his new understanding of the passions did not allow him to return to ancient religion or recover Aristotelian 'magnanimity'. ${ }^{16}$ He diagnoses honor as the most dangerous passion and the origin of tyranny, violence and all political instability and like all other passions, it cannot be stopped or checked by reason or exhortation. Yet properly diked, its full and powerful flow is the only way of securing stability and republican freedom (D I, 42; III, 1; P 25, p. 98). 
Politics, according to Machiavelli, is defined by enduring and defining struggle between the few great (grandi) who desire to command and oppress, and the many (popoli) who seek not to be commanded or oppressed (P 3, pp. 14-15; D I, 37, p. 78; P 9, p. 39). ${ }^{17}$ This political expression of the natural desire to acquire also reveals the pathology of honor for Machiavelli. The few, in attempting to satisfy their desire to acquire, reach beyond mere acquisition of property to gaining hearts and minds. Thus Machiavelli discerns in the ambition (ambizione) of the few the desire to rule, and thereby dominate, command and oppress, displaying pride, haughtiness or the passion of honor as pre-eminence or glory. ${ }^{18}$ This desire is so strong that it will evade or even undermine legal or constitutional means, relying on the illegal or violent to advance one's interest rather than common good or welfare of the state. In this account of the few and many Machiavelli appears to adopt the classical distinction between the two faces of honor, of glory (gloria) and honor (onore). But in a crucial respect he repudiates the classical view that honor as the desire to be loved and admired has its source in the longing to be noble or beautiful. Fear, not love, is at the heart of honor according to Machiavelli. The psychology of honor of the few is driven by the logic of fear: 'the order of these accidents is that when men seek not to fear, they begin to make others fear; and the injury they dispel from themselves they put upon another, as if it were necessary to offend or to be offended' (D I, 46, p. 95).

Compared to the few, the many seem more honorable. ${ }^{19}$ Indeed, Machiavelli praises them as more pious (D I, 11), law-abiding (D I, 58), decent (P 9), and moral (D I, 7) than the few. While the many in their disdain of glory seem more noble, they too are driven by an original terror. The piety of the people, for example, and their credulity derives from their fear of punitive gods and those who speak on their behalf (D I, 11; 12-13; 29; 54-56). Aware of their weakness and fearing change, the people are deeply conservative, favoring rest over movement, peace over war, old over new (D I, 48; III, 6). They cling to laws to 
satisfy the order and stability they crave (D I, 58, pp. 39-40; III, 5). ${ }^{20}$ Significantly, the desire for freedom has its source in fear: 'He will find that a small part of them desires to be free to command, but all others, who are infinite, desire freedom so as to live secure’ (D I, 16, p. 46). Therefore the many seek and value honor but only instrumentally, so that where there is a tension between the two, it would seem that the 'men esteem property more than honours' because it is more valuable (D I, 37, p. 80; P 17, p. 67).

Machiavelli's wholly new conception of glory and honor accounts for its crucial role in his political thought and how he deals with it. The first task is a rehabilitation of glory that repudiates the contemporary lack of spirit (ignavia) and ambitious leisure (ozio) by liberating and celebrating the spirit of daring of the few young. Fortuna, according to Machiavelli, 'lets herself be won more by the impetuous than by those who proceed coldly' (P 25, p. 101). ${ }^{21}$. Machiavelli's second endeavor is to instruct the few on modi or how to acquire rule. Machiavelli teaches that there is a fundamental tension between the desire of the few to be loved and admired, and their longing to acquire and keep political rule. The 'very praiseworthy' virtues are qualities that the prince cannot have, nor wholly observe, 'since human conditions do not permit it' (P 15, p. 62). Certainly the prudent prince will avoid infamy because it is useful to appear 'merciful, faithful, humane, honest and religious' (P 18, p. 70). But 'one should not care incurring the fame of those vices without which it is difficult to save one's state' (P 15, p. 62). Machiavelli's new teaching recalibrates the value of honor in politics, seemingly counseling a shamelessness that liberates tyrannical ambition. This education is countered, however, by a third approach that repudiates tyranny. His lessons on ordini or new foundations show how worldly glory (mondana Gloria) proves to be a philosopher's stone transmuting personal ambition into public spirited defense of a free community (uno vivere libero) and a 'well ordered republic'. 
Unlike all other forms of acquisition, honor requires the opinion or judgment of others. This means that glory-seekers are compelled to consider the views or interests of others, even if for the instrumental purpose of satisfying oneself. ${ }^{22}$ Glory is therefore the only selfregarding passion that is intrinsically and unavoidably concerned with the common advantage, if not the common good. Of the different forms of glory, the highest according to Machiavelli is found in politics, in the double glory (duplicata gloria) of those who found republics or kingdoms (P 24). The glory of the founder, derived from the love of the many for the safety and other benefits they have received, is a comprehensive good for the ambitious few. It secures the greatest acquisition, the founding, by ensuring the glory, honor, security, quiet, and satisfaction of mind of the founder (D I, 10, p. 31). It also perpetuates one's name and reputation beyond the founding, the only form of immortality available sub specie aeternitatis. ${ }^{23}$ By contrast, tyrants, deceived by a ‘false good and a false glory’, gain instead of fame, glory and honor, ‘infamy, reproach, blame, danger and disquiet’ (D I, 10). In promising the complete satisfaction of individual glory Machiavelli seems ambivalent between political orders, especially between princely and republican rule. On closer inspection, however, the thoughtful prince will see the advantages of founding a republican order. Glory favors republics because they are founded upon laws and institutions that allow able successors, select leaders who suit the times, while assuring patriotic citizens who will defend the republic. More stable and enduring longer, they are better able to preserve and celebrate the glory of the founder.

Machiavelli accepts the two faces of honor, especially the potential dangerousness of glory-seekers who desire to dominate. He denies, however, that education in magnanimity is a remedy for glory. ${ }^{24}$ Machiavelli wants to use the vigor and dangerousness of glory to secure political stability and republican liberty. The other-regarding and therefore profoundly political aspect of glory makes its complete satisfaction the basis for common political 
advantage between the glory and honor lovers. Machiavellian virtù is now therefore interpreted as a new prudence of 'picking the less bad as good" in order to be both feared and loved (P 21, p. 91; P 17, p. 66). The Machiavellian recovery of modern glory reconciles the two faces of honor, security of rule and more expansively immortal glory of the few with the safety and prosperity of the many (D I, 4).

\section{Hobbes, the 'Lord over the Children of Pride'}

Machiavelli's teaching on glory and honor initiated an important modern understanding of the politics of honor. This innovation would soon confront a new approach that accepted Machiavelli’s major premises but rejected its core teaching on glory. Unlike Machiavelli, Hobbes repudiates both glory and honor and in doing so seems to agree with those who diagnosed in honor and chivalry the pathologies of feudal life. ${ }^{25}$ Yet Hobbes differs from these approaches in profound ways. Honor is certainly a central concern of Hobbes, but his ambition is not confined to the repudiation of feudal nobility; based on his new concept of power and honor, he seeks to redefine and refound all of politics.

The centrality of honor for Hobbes's political thought is signalled by the very title of his most famous and influential work, Leviathan ${ }^{26}$ Hobbes's Leviathan, unlike the Old Testament's creature of the Lord set over the children of pride (Job, 41: 34), is an artificial body, made by the 'Art of man', whose business is Salus Populi (L Introduction, p. 81). Pride, it would seem, is not the greatest sin, but a political problem to be remedied by human ingenuity. But what exactly is Hobbes's understanding of pride and honor, and why is it a political problem ${ }^{27}$

Hobbes introduces his new conception of honor in the Leviathan, Chapter X 'Of Power, Worth, Dignity, and Worthiness'. As the chapter title suggests, Hobbes’s conception of honor is essentially linked to his innovation of 'power'. Hobbes denies the classical claim that 
humans are 'Politcall creatures' or lovers of some 'greatest Good' (L 17, p. 225; L 11, p. 160). Nature, 'the Art whereby God hath made and governs the World' gives no positive directions or aims: 'For there is no such Finis ultimus, (utmost ayme,) nor Summum Bonum, (greatest Good) as is spoken of in the Books of the old Morall Philosophers' (L Introduction, p. 81; L 11, p. 160). Therefore, 'The Power of a Man', according to Hobbes, is 'his present means, to obtain some future apparent Good' (L 10, p. 150). Having defined power, Hobbes is in a position to redefine the meaning of 'Worth', 'Dignity' and 'Honour'. 'The Value, or Worth of a man, is as of all other things, his Price; that is to say, so much as would be given for the use of Power: and therefore is not absolute; but a thing dependant on the need and judgment of another' (L 10, p. 151). Hobbes denies that we are inherently valuable - no matter how highly we value ourselves, our price is determined by the 'buyer', that is, others and not us, the 'seller'. Consequently, 'Honourable is whatsoever possession, action, or quality, is an argument and signe of Power' (L 10, p. 155). Honor as a measure of power allows Hobbes to redefine the meaning of 'Dignity' and 'Worthiness'. Dignity is not inherent, natural or derived by our own actions. Rather, the 'publique worth of a man', according to Hobbes, ‘is the Value set on him by the Common-wealth' (L 10, p. 152). Taken together, these observations make us realize that there is nothing honorable about honor for Hobbes. 'Honorable' or honor is a 'sign' of power, a measure of ability to acquire future goods. Since our power (and therefore our honor) is always changing because our power derives from the will and opinion of others (the purchaser will determine the price), it is subject to the accuracy of their judgment, which inevitably relies on the appearance of power, that is, our fame or reputation of power. Consequently, as ‘Reputation' or 'Fame’, honor itself is a form of 'Instrumentall' power.

Hobbes's conception of power suggests he intends to undermine honor altogether by questioning the foundations that sustain our hopes and beliefs that we are worthy, have 
dignity and therefore are honorable. Natural abilities, such as physical strength and beauty, innate ability, perspicacity or judgment cannot be inherently honorable because they are not reliably powerful to warrant such a claim. Just as the moral virtues, such as justice, cannot be the foundation of honor, neither can birth or nobility - Hobbes seems to take particular pleasure in humiliating his betters with his historical account of 'Coats of Armes' and the mean and dishonorable origins of all claims to nobility. Importantly, his deafening silence in this chapter on divine preferment, of the power of saints, prophets and priests, is telling. ${ }^{28}$

Hobbes’s ambition to uncouple honor from excellence and reduce it to an aspect of power (its measure and an instrument) seems indifferent to the two faces of honor. But as we will see, Hobbes knows of the distinction between glory and honor and is especially concerned with the dangerousness of glory. His strong medicine, the depreciation of honor, is needful, he would claim, because it is the only remedy for destroying the seeds of pride or vaine-glory. To see the pathology of pride, it is necessary to understand what Hobbes considered the causes of war.

The state of nature is a state of war for Hobbes due to three causes: competition, diffidence and glory (L13, p. 185). The diffident are 'moderate' and 'reasonable' who invade for 'Safety' and use Violence only to defend themselves and their possessions (L 11, p. 161; L 13, p. 185). The competitive are less moderate than the diffident because they use violence not just for safety but gain, seeking mastery over 'mens persons, wives, children and cattell' (L 13, p. 185). But because 'Mastery' is no more than evidence of gain for the competitive, their need to master is circumscribed and limited by material gain. Glory poses a more intractable political problem because it seems to lack the inherent limits on violence exercised by the safety-seeking diffident and the acquisitively competitive.

Glorying, according to Hobbes, is a type of 'Joy', a pleasure or 'exultation of the mind' arising from ‘imagination of a mans own power and ability’ (L 6, pp. 122-125). Beyond the 
'short vehemence' of ‘carnall Pleasure' open to all people, contemplating one’s ‘own power in the acts of conquest', results in intense delight ( $\mathrm{L} \mathrm{13,} \mathrm{p.} \mathrm{184).} \mathrm{Some} \mathrm{glory-seeking} \mathrm{is} \mathrm{to} \mathrm{be}$ expected of all people because even the most 'moderate' person naturally demands some value be placed on their person and finds joy in 'comparing himselfe with other men' and judging himself 'eminent’ (L 17, p. 226). But Hobbes also notes that glory-seekers often pursue glory 'farther than their security requires', creating the problem that some seek glory even at the risk of their lives ( $\mathrm{L} \mathrm{13,} \mathrm{p.} \mathrm{185).} \mathrm{For} \mathrm{these} \mathrm{people,} \mathrm{glory} \mathrm{becomes} \mathrm{disengaged} \mathrm{from}$ its source in the pursuit of the power needed to preserve their vital motion. The intense nature of the pleasure of actual conquest is one reason why some place glory above security. But there are more complex forces at work as we can see from Hobbes's assessment of the person who invades for 'Reputation':

For every man looketh that his companion should value him, at the same rate he sets upon himselfe: And upon all signes of contempt, or undervaluing, naturally endeavours, as far as he dares (which amongst them that have no common power, to keep them quiet, is far enough to make them destroy each other,) to extort a greater value from his contemners, by dommage; and from others, by example (L 13, p. 185).

The foundational human problem that exacerbates our dealings with each other is our need to 'value' ourselves higher than our neighbors. This is compounded by our inability to construe 'signs' of valuing because we are unable to see internal motions, compelling us to attempt to read external signs, so that 'trifles', such as ‘a word, a smile, a different opinion' become signs of undervalue ( $\mathrm{L} \mathrm{13,} \mathrm{p.} \mathrm{184).} \mathrm{These} \mathrm{trifles} \mathrm{become} \mathrm{as} \mathrm{important} \mathrm{as} \mathrm{those} \mathrm{gross} \mathrm{signs} \mathrm{of}$ security such as mastery of people and things that comfort the diffident and the competitive. But their subtlety and fleeting aspect, combined with our suspicion that we are being undervalued, makes them easy to misconstrue. Finally, the glory-lover can be slighted by 'reflexion' - by undervaluing 'their Kindred, their Friends, their Nation, their Profession, or 
their Name'. Glory seems to expand beyond the individual to an ever-expanding conception of oneself (L 13, p. 185). This, of course, is part of the intense pleasure of Glory, the feeling of being bigger, greater, or more majestic. Indeed, the glorious falls in love with his reputation because ‘extraordinary power’ continually satisfies the never-ending desire for power. Yet such passionate attachment to glory and its feeling of enlargement exposes the glorious to greater risk of undervaluing and therefore anxiety, demanding greater vigilance and attention in ensuring their glory.

The difficulties in establishing true valuation pale in comparison with what is required to restore the joy or pleasure of glory upon being slighted. The glory-lover needs to 'extort a greater value from his contemners, by dommage; and from others, by example' (L 13, p. 185), which means that the glory-lover must prove his worth by publicly threatening or injuring those who have slighted him, extracting a concession of superiority and thereby a public display of power. In doing so the glory-lover is compelled to risk himself to show his power. Sustaining the joy that is glory may necessitate harming his body or undermining his power as property. In the extreme case, the glorious may risk his own life to show his power. Therefore, the pleasure of glory is not checked by the moderating demands of security and property in two senses. The first is in the sense that we have noted - the glorious will illogically sacrifice his life for his name. The second is that the pleasure of glory seeks to ever-increase its delectation - glory will in social terms seek ever greater mastery, at the risk of security. Of the three causes of quarrel, glory or pride as a struggle over valuing is the most dangerous because it has no reasonable stop, tends to escalate and is essentially political. That the glorious initiate the struggles that compel the competitive and the diffident into unreasonable warfare is the principal reason pride is the political problem for Hobbes. ${ }^{29}$ Hobbes agrees with Machiavelli on the dangerousness of glory and the pervasiveness of fear in politics. He rejects altogether Machiavelli's solution that sees glory as its homeopathic 
antidote. Glory for Hobbes is a form of madness that cannot be manipulated and therefore must be extirpated. Hobbes's strategy is therefore twofold, a new way of thinking about honor, and a new politics in the spirit of the fundamental Law of Nature, 'That every man acknowledge other for his Equall by Nature’ (L 17, p. 223). His principal means of becoming lord over the children of pride is a radically new conception of political authority as a neutral and democratic 'power', with the redefinition of honor as a sign or form of power. Relying on rhetoric, or on a Euclidian joining up of words as 'reackoning', Hobbes will now make all substantive claims of honor inherently dubious or questionable. In doing so Hobbes removes the shame that historically accompanied individual claims of rights - indeed the assertion of one's own interest and entitlement is now seen to be consistent with, or advancing the welfare of all when political authority is seen as that 'Artificiall Man', the 'great LEVIATHAN called a COMMON-WEALTH, or STATE', made to secure peace (L Introduction, p. 81). Though desires and passions are 'in themselves no Sin', they are contrary to the laws of nature, requiring the sovereign to use 'terrour' to keep all in awe. Hobbes's political solution for the 'miserable condition of Warre' therefore relies on the modern artifice of the Leviathan state that deploys fear, the most reasonable of passions, to counter passions (L 13, p. 187; L 15, p. 211). Hobbes's well-known social contract is therefore founded not on the dynamic tension between the few and the many, as Machiavelli advocates, but on the diffident and the competitive, who have foresight and want to leave the state of war to preserve themselves and secure a more ‘contented life’ (L 17, p. 227).

\section{Modernity and Honor}

Though agreeing on a range of core questions, Machiavelli and Hobbes fundamentally diverge on the meaning of honor and its implications for politics. These two contending positions in modernity, I suggest, have persisted and been influential in shaping subsequent 
modern debates on honor and arguably the character of modernity itself. In this context it is instructive to note briefly the remarkable persistence of each approach, as well as the significant ways each has been altered or modified to accommodate new concerns. ${ }^{30}$

Hobbes's ruthless debunking of honor proved to be very influential for subsequent thinkers. For liberals such as Locke an important part of education consisted in the moderation of the wilfulness of the young. ${ }^{31}$ Honor and its political treatment was also a central concern for those critical of the Hobbesian solution. Rousseau accepted the decisive political significance of amour-propre or honor but charged Hobbes and Locke with exacerbating the problem by encouraging competition for honor, desire for superiority and thereby the inauthentic individualism of the bourgeois. Rousseau's solution to the problem of the bourgeois took two diverse paths, mooring honor in the wholeness of patriotism and patrie, or in the authenticity possible only at the margins of society. ${ }^{32}$ Rousseau's endeavor to salvage natural freedom and integrity from feverish modernity significantly influenced subsequent attempts to recover a richer conception of honor while acknowledging its pathologies. Drawing on Rousseau’s volonté générale, Kant argued that all rational beings had autonomy of will, 'the property of the will by which it is a law to itself', a form of selfgovernance by legislating universal laws. It was this autonomy, as the 'ground of the dignity of human nature and every rational being', that distinguished between those things that had a price or relative worth, from those that had an inner worth or dignity. Consequently for Kant rational beings as ends in themselves had unconditional, incomparable worth or dignity that warranted respect. ${ }^{33}$ For Hegel the rehabilitation of honor took the form of recognition. The individual subject's desire for satisfaction resulted in a life or death struggle for recognition that ended either in death, or in mastery by the one who does not fear death, over the slave who sought to preserve life by giving up independence and recognition. Yet for Hegel this outcome could not give rise to a full consciousness of freedom because the master needed 
recognition but could not satisfy it because it is given through coercion of the servile consciousness of the slave, and the slave in turn in seeking to preserve life gave everything away to the master. It was only through the transforming and liberating labor of the slave, according to Hegel, that full consciousness of freedom and ethical union could be achieved, when the master and the slave each 'recognize themselves as reciprocally recognizing each other', so that the 'I' becomes a 'We' or spirit. ${ }^{34}$ The concepts of authenticity, autonomy and recognition can therefore be seen as ambitious attempts to recover or rehabilitate a richer conception of individual honor. What is notable about all these attempts was the consistent commitment to egalitarianism, and an approach that located the source of honor beyond the political - authenticity, autonomy, and recognition had their origins in our very humanity, rather than in the rankings ordered by political or civil society. But in an important respect all these attempts continued to acknowledge the Hobbesian insight into the dangers of honor. In recovering equal honor, these approaches repudiated completely its other face - of honor as glory or pre-eminence. A striking example reveals the general disposition: Hegel's 'recognition' denies Napoleon any personal glory; he is a 'world historical figure' used by the ‘Cunning of Reason’ to be an agent of World Spirit (Philosophy of History, Book III, §33).

The Machiavellian conception of glory, though less prominent than the Hobbesian elevation of honor over glory, was also influential in the subsequent understanding of the passion. Here too we find an increasing emphasis on the importance of this face of honor, at the expense of the other. Montesquieu, for example, acknowledges his debt to Machiavelli, but devises new institutions to channel productively the passion of glory to secure freedom. ${ }^{35}$ Nietzsche too praises Machiavelli, and in doing so attacks the 'herd animal' and equality of rights. He intends to recover the 'rare, strange, privileged, the higher man, the higher soul, the higher duty, the higher responsibility, and the abundance of creative power and masterfulness' (Beyond Good and Evil, section 212). In doing so he wants to reintroduce a 
new ordering of rank with the highest man being the philosopher as 'legislator' and 'creator', the lawbreaker who breaks the tablets of values (Zarathustra, Section 9). Men such as Napoleon 'must come again and again' according to Nietzsche, though the new Napoleon will be ‘a Caesar with a Christ’s soul’ (Will to Power, No 983; Glenn, 2001).

The contrasting views of Nietzsche and Hegel regarding Napoleon, and more generally Nietzsche's master and slave morality as a repudiation of Hegel can be revealingly interpreted as a re-enactment of the Hobbes-Machiavelli debate on the importance of glory and honor for humanity. ${ }^{36}$ Of course there are now new elements uniquely shaping the debate, not least the importance of history as well as 'creativity', and 'recognition'. Yet the opposing views regarding the two faces of honor remain powerfully dominant, configuring the politics of both thinkers and all those they influenced.

\section{Prestige, Self-Esteem, Recognition, Dignity}

We started our inquiry by noting the apparent tension between the obsolescence of honor and the central role of self-esteem, recognition and dignity in modern thought and practice. This tension can now be seen as an aspect of the debate at the core of modernity regarding the meaning of honor, where the dominance of the Hobbesian understanding tends to conceal a continuing persistence of diverse perspectives that attempt to improve upon it, or escape its influence. The Hobbesian minimalist conception of honor as a measure of instrumental power to be calculated, preserved and deployed continues to exercise an extraordinary influence, ranging from the international relations idea of honor as 'prestige', or 'soft power', to economics where it remains unassailed, to its deployment in marketing and public relations, especially in the study of fame, celebrity and 'brand' marketing. ${ }^{37}$

Aware of the limitations of seeing honor as a measure of power, a number of scholars have attempted to recover a more comprehensive understanding of honor for the study of 
politics. Yet to the extent that these approaches have accepted or been unwilling to question the modern origins of honor, their approach has confronted fundamental obstacles, as we can see in both the liberal and critical scholarship. As we saw, understanding honor as 'dignity' and 'recognition' presumed its intrinsic goodness and sought to distribute it equally. Yet it is not clear whether honor is comparable to other good things such as property, rights and freedoms, and therefore capable of equal distribution in the same way, or whether it is fungible, commensurate and potentially interchangeable with these other good things. We can see these difficulties in the contemporary attempts to reconcile equal rights with 'selfesteem', ‘dignity’ and 'recognition'. John Rawls in A Theory of Justice acknowledges that 'perhaps the most important primary good is that of self-respect' (1971, p. 440; emphasis added). Yet the bulk of the book focuses not on self-respect (§67), but on those primary goods such as rights and wealth that are capable of equal distribution (Rawls, 1971, p. 62). The reason for this, it would seem, is that Rawls' justice as fairness can only speak of honor in truncated terms of 'self-respect' or 'self-esteem' because it is only these self-regarding notions that can accommodate the 'thin' conception of the good that is required in the original position. Rawls, in other words, has to reinterpret and limit honor to ensure it does not undermine his entire undertaking. ${ }^{38}$ This debate in liberalism is in important respects reenacted in the critical scholarship. ${ }^{39}$

Other scholars have tried to overcome the limitation of the Hobbesian approach by turning to Machiavelli. ${ }^{40}$ In leadership studies the emphasis by participatory, deliberative and associative democrats on the merits of horizontal power structures and the importance of ‘followership' has in effect denied leaders any significance. In recovering an important role for leaders MacGregor Burns’ influential Leadership (1978) in effect reintroduces a Machiavellian 'transformative' leader as a necessary public-spirited counter and antidote to the Hobbesian 'transactional' leader he finds contemptibly instrumental. ${ }^{41}$ In doing so, 
however, he appears to have no principled basis in distinguishing between transformative leaders he regards as 'idols', who satisfy their powerful need for 'affection, esteem, and selfactualization' by satisfying the needs of followers including ‘their need for esteem from performers who bestow recognition and flattery on them - and thus by their need for selfesteem', and those leaders who are 'moral' or 'authentic', who in his tellingly ambiguous formulation, 'lead by being led' (1978, pp. 246, 248, 117).

This brief overview reveals the extraordinary reach and influence of modern honor in contemporary political studies, especially in its Hobbesian aspect. It also shows how the various attempts to repair or rehabilitate aspects of Hobbesian honor have resulted in a diminution of the concept, as can be seen in the idea of self-esteem, depoliticized 'dignity', or 'authentic' leadership. Such diminution is evident above all in the modern tendency to uncouple honor from virtue and excellence, issuing in a procrustean dogmatism that is unable to accommodate the noble ambition of the magnanimous or the subtle authority of humility. It would seem, therefore, that the success of modern honor over classical and pious conceptions may be at the expense of clarity regarding the nature of the passion and its force in politics. An adequate assessment of the predominance of modern honor will therefore warrant a more considered reflection on the classical and pious challenge to modern honor that is free from modernity's bias; it is only by recovering the larger debate and contest that issued in modernity, by tracing the lineaments of these older conceptions, that we are able to judge the success of modern honor, and the price of its victory.

\section{Notes}

\footnotetext{
${ }^{1}$ See, for example, Hasan (2002) on 'crimes of honor' such as sororicide and filicide.

${ }^{2}$ See Berger (1984); Bowman (2006), who argues we live in a 'post-honor' society, as well as Stewart (1994); Krause (2002); Oprisko (2012).
} 
${ }^{3}$ On self-interest see Hirschman (2013); Mansfield (1995); Fraser and Honneth (2003). On game theory and strategic choice see generally Mueller (1989); Alt and Shepsle (1990); Green and Shapiro (1994).

${ }^{4}$ See Braudy (1997) on the 'frenzy' of fame.

${ }^{5}$ See, for example, studies of Mediterranean honor (Peristiany 1966), Bedouin honor (Stewart 1994), Southern honor (Wyatt-Brown 1982) and Asian 'face' (Benedict 2005).

${ }^{6}$ For an overview of the classical conception of honor see Konstan (2007); Harris (2001). On the importance of eros and epithumia or spiritedness as the source of time or honor in Plato see Pangle (1976); Pangle's 'Interpretive Essay on the Laws in Plato' (1980, especially pp. 452-457); and Pangle (2009).

${ }^{7}$ On the importance of honor for heroism and the 'code of the warrior' see French (2003).

${ }^{8}$ See generally Plato's Symposium, Phaedrus and Phaedo and Ahrensdorf (2000) regarding the longing for immortality as an important element of honor.

${ }^{9}$ On the Greek to kalon or the noble and the Latin honestas see Welsh (2008, pp. 40-49).

${ }^{10}$ See the discussion in Plato's Republic, 548c and more generally Book VIII. See also Bloom (1991); Craig (2006).

${ }^{11}$ The prophecy was that whoever untied the knot of cornel wood on a wagon dedicated by Midas, son of Gordius, would be the next ruler of Asia (see Plutarch, Lives; Alexander, 18.4).

${ }^{12}$ On Alcibiades see Plato’s Alcibiades I and II; Forde (1989) and Faulkner (2007, pp. 58-126).

${ }^{13}$ These will include the 'noble lies' (Republic, 414b-415d), as well as the Myth of Er (Republic, 614-621).

14 'In the sweat of thy face shalt thous eat bread, till thou return unto the ground; for out of it wast thou taken: for dust thou art, and unto dust shalt thou return' (Genesis, 3, p. 19).

${ }^{15}$ References to the Discourses on Livy are by book, chapter, page (Machiavelli 1996); to the The Prince, by chapter and pages (Machiavelli 1985).

${ }^{16}$ On magnanimity see Aristotle, Nicomachean Ethics (1095b; 1123b-1124b). On the importance of glory and honor for Machiavelli, see Strauss (1959); Price (1977); Eldar (1986); Santi (1979); Varotti (1998); Kahn (1993); Zmora (2007).

${ }^{17}$ This difference is due to 'humors' (umori) or 'appetites' (appetiti): Price (1982); Parel (1990); Fischer (1997).

${ }^{18}$ For a detailed overview see Price (1982). Thus we see the few desire to rule (regnare: D III, 4, 14), dominate (dominare: D I, 5; III, 6); tyrannize (tiranneggiare: D I, 40), command (comandare: P 9), oppress (opprimere: P 9) the people, displaying pride or haughtiness (superbia: D I, 3) or insolence (insolenzia: P 9; D I, 2; III, 46).

${ }^{19}$ For Machiavelli's democratic preferences see, for example, McCormick (2011).

${ }^{20}$ It is the weakness and vulnerability of the many that will especially dispose them to a high-minded morality (D III, 20-23; I, 35, 40).

${ }^{21}$ See Patapan (2003) on Machiavelli's theogony.

22 'The desire for immortal glory' according to Strauss (1958, p. 286), 'is the link between badness and goodness, since while it is selfish in itself, it cannot be satisfied except by the greatest possible service to others'. For Santi (1979, p. 126) it harmonizes the private good with the common weal. It is for Eldar (1986, p. 422) a 'mediated acquisition'.

${ }^{23}$ See Zmora (2007).

${ }^{24}$ There are only two references to magnanimous (magnanimo) in Machiavelli's major political works. In The Prince (P 7, p. 32) Machiavelli notes how his model, Cesare Borgia, used force and fraud, and made himself loved and feared by the people and was 'severe and pleasant, magnanimous and liberal'. Magnanimity, it would seem, is an instrumental virtue, but one of the many ways a new prince can maintain a principality. This new Machiavellian understanding of magnanimity is clarified and confirmed in the Discourses (III, 34, p. 289), where Machiavelli notes how princes can maintain reputation: 'For nothing makes them so much esteemed as to give rare examples (sé rari esempli) of themselves with some rare act or saying conforming to the common good, which shows the lord either magnanimous, or liberal, or just, and is such as to become like a proverb among his subjects'. 
Machiavelli here indicates that magnanimity is not a comprehensive virtue of character but a politically useful reputation that can be acquired or engineered by 'rare' but memorable actions. ${ }^{25}$ See, for example, Cervantes's Don Quixote, Shakespeare’s Falstaff, nicely poised between Hotspur and Hal, declaiming that honor is 'A word', 'Air' or 'a mere scutcheon' (Henry IV, Part I, V.1); Montaigne’s ‘Of Glory' and Bacon's Essays ‘Of Vain-Glory' and 'Of Honour and Reputation'. ${ }^{26}$ Reference to Hobbes's Leviathan is as follows: Leviathan (L, chapter, and page number) (Hobbes 1968).

${ }^{27}$ For the scholarship see generally Strauss (1953); Slomp (2000); Hampton (1989); Sacksteder (1989) and Altman (1989).

${ }^{28}$ His passing remark on divine providence at the start of the chapter, that 'the secret working of God, which men call Good Luck', is indicative of his judgment generally (p. 150).

${ }^{29}$ Without pride, the diffident (and perhaps the competitive to a great degree) could lead a life as peaceful and productive as those of bees or ants (L 17, p. 225).

${ }^{30}$ For detailed accounts on the changing theoretical conceptions of honor see, for example, Hirschman (2013); Faulkner (2007, especially chapters 7 and 8); Krause (2002); Welsh (2008); Pangle (1999).

${ }^{31}$ See especially Locke's Thoughts on Education and Tarcov (1999).

${ }^{32}$ On patrie as a solution to the pathologies of amour-propre see for example Rousseau's Political Economy and The Government of Poland. His Reveries of a Solitary Walker explores the possibility of authenticity in modern life. For a general discussion of these themes see Douglass (2015); Cladis (2000).

${ }^{33}$ See generally Groundwork of Metaphysics of Morals 4, p. $434 \mathrm{ff}$. On the differences between the Kantian conception of autonomy and its modern formulations see Sensen (2013).

${ }^{34}$ See Phenomenology of Spirit, Part B, IV, sections 166-230.

${ }^{35}$ On Montesquieu's use of institutions to channel ambition or the 'desire to do great things' see Krause (2002, pp. 32-66, especially p. 59).

${ }^{36}$ See Williams (2012) on the contrast between Hegel and Nietzsche.

${ }^{37}$ On prestige in international relations see Nye (2004); Schelling (1960); and Mercer (1996). For the 'economy of esteem' see Brennan and Pettit (2005). On political marketing see Lees-Marshment et al. (2014).

${ }^{38}$ On attempts to overcome these difficulties see generally Taylor (1991), Cooke (1997) and Walzer (1983, chapter 11) who criticizes the entire approach on the basis that it denies excellence.

${ }^{39}$ See Fraser and Honneth (2003).

${ }^{40}$ On Machiavelli's influence on elitism studies see Putnam (1976); Nevitte and Gibbins (1990); Higley and Burton (2006).

${ }^{41}$ It is not sufficiently appreciated that Burns acknowledges the importance of 'unfulfilled esteem needs' (1978, p. 113; emphasis in the original) for understanding political motivation and ambition. 


\section{References}

Ahrensdorf, P.J. (2000) The fear of death and the longing for immortality: Hobbes and Thucydides on human nature and the problem of anarchy. American Political Science Review 94 (3): 579-593.

Alt, J. and Shepsle, K. (eds.) (1990) Public Choice Perspectives on Positive Political Economy. Cambridge, UK: Cambridge University Press

Altman, A. (1989) Glory, respect, and violent conflict. In: P. Caws The Causes of QuarrelEssays on Peace, War and Thomas Hobbes. Boston: Beacon Press, 114-127.

Appiah, K.A. (2010) The Honor Code. New York: Norton and Company.

Benedict, R. (2005) Chrysanthemum and the Sword. Boston: Houghton Mifflin Co.

Berger, P. (1984) On the obsolescence of the concept of honour. In: M. Sandel (ed.)

Liberalism and its Critics. Oxford: Basil Blackwell, 149-158.

Bloom, A. (1991) Interpretive essay. In: A. Bloom (ed.) Plato’s Republic, Translated by A. Bloom . New York: Basic Books.

Borowitz, A. (2005) Terrorism for Self-Glorification. Kent: Kent State University Press.

Bowman, J. (2006) Honor: A History. New York: Encounter Books.

Braudy, L. (1997) The Frenzy of Renown: Fame and its History. New York: Vintage Books.

Brennan, G. and Pettit, P. (2005) Economy of Esteem. Oxford: Oxford University Press.

Burns, J.M. 1978. Leadership. New York: Harper \& Row.

Cladis, M.S. (2000) Redeeming love: Rousseau and eighteenth-century moral philosophy. Journal of Religious Ethics 28(2): 221-251.

Cooke, M. (1997) Authenticity and autonomy: Taylor, Habermas, and the politics of recognition. Political Theory 25(2): 258-288.

Craig, L.H. (2006) The War Lover. Toronto: University of Toronto Press. 
Douglass, R. (2015) Rousseau and Hobbes. Oxford: Oxford University Press.

Eldar, D. (1986) Glory and the boundaries of public morality in Machiavelli’s thought. History of Political Thought 7(3): 419-438.

Faulkner, R. (2007) The Case for Greatness. New Haven: Yale University Press.

Fischer, M. (1997) Machiavelli’s political psychology. The Review of Politics 59(4): 789829.

Forde, S. (1989) The Ambition to Rule. Ithaca: Cornell University Press.

Fraser, N. and Honneth, A. (2003) Redistribution or Recognition? A Political-Philosophical Exchange. London: Verso.

French, S. (2003) The Code of the Warrior. Lanham: Rowman and Littlefield.

Glenn, P.F. (2001) Nietzsche’s Napoleon: The higher man as political actor. The Review of Politics 63(1): 129-158.

Green, D.P. and Shapiro, I. (1994) Pathologies of Rational Choice Theory. New Haven: Yale University Press.

Hampton, J. (1989) Hobbesian reflections on glory as a cause of conflict. In: P. Caws (ed.) The Causes of Quarrel - Essays on Peace, War and Thomas Hobbes. Boston: Beacon Press, 78-96.

Harris, W.V. (2001) Restraining Rage. Cambridge: Harvard University Press.

Hasan, M. (2002) The politics of honor: Patriarchy, the state and the murder of women in the name of family honor. Journal of Israeli History: Politics, Society, Culture 21(1-2): 137.

Hegel, G.W.F. [1807] (1977) Phenomenology of Spirit, Translated by A.V. Miller. Oxford: Oxford University Press.

Higley, J and Burton, M. (2006) Elite Foundations of Liberal Democracy. Lanham, MD: Rowman and Littlefield. 
Hirschman, A.O. (2013) The Passions and the Interests: Political Arguments for Capitalism before its Triumph. Princeton: Princeton University Press.

Hobbes, T. (1968) Leviathan, Edited by C.B. Macpherson. New York: Penguin Books. Kahn, V. (1993). Virtù and the example of Agathocles in Machiavelli’s Prince. In: A.R. Ascoli and V. Kahn (eds.) Machiavelli and the Discourse of Literature. Ithaca: Cornell University Press, 195-217.

Konstan, D. (2007) The Emotions of the Ancient Greeks. Toronto: University of Toronto Krause, S.R. (2002) Liberalism with Honour. Cambridge, Mass.: Harvard University Press. Lees-Marshment, J., Conley, B. and Cosgrove, K. (eds.) (2014) Political Marketing in the US. New York: Routledge.

Machiavelli, N. (1985) The Prince, Translated by H.C. Mansfield Jr. Chicago: University of Chicago Press.

Machiavelli, N. (1996) Discourses on Livy, Translated by H.C. Mansfield Jr. and N. Tarcov. Chicago: University of Chicago Press.

Mansfield, H.C. (1995) Self-interest rightly understood. Political Theory 23(1): 48-66. McCormick, J.P. (2011) Machiavellian Democracy. Cambridge: Cambridge University Press. Mercer, J. (1996) Reputation and International Politics. Ithaca: Cornell University Press. Mueller, D. (ed.) (1989) Public Choice II. Cambridge, UK: Cambridge University Press. Nevitte, N. and Gibbins, R. (1990) New Elites in Old States: Ideologies in the AngloAmerican Democracies. Oxford University Press: Toronto.

Nye, J. (2004) Soft Power: The Means to Success in World Politics. Washington: Public Affairs (Perseus Books).

Oprisko, R.L. (2012) Honor: A Phenomenology. New York: Routledge. Pangle, L.S. (2009) Moral and criminal responsibility in Plato’s Laws. American Political Science Review 103(3): 456-473. 
Pangle, T.L. (1976) The political psychology of religion in Plato’s Laws. American Political Science Review 70(4): 1059-1077.

Pangle, T.L. (1980) The Laws of Plato. New York: Basic Books.

Pangle, T.L. (1999) The classical and modern liberal understandings of honor. In: P. McNamara (ed.) The Noblest Minds: Fame, Honor, and the American Founding. Lanham: Rowman and Littlefield, 207-220.

Parel, A. (1990) Machiavelli's use of umori in The Prince. Quaderni Italianistica 11(1): 91101.

Patapan, H. (2003). I Capitoli: Machiavelli's New Theogony'. The Review of Politics 65 (2) 185-207.

Peristiany, J.G. (ed.) (1966) Honour and Shame: The Values of Mediterranean Society. Chicago: The University of Chicago Press.

Price, R. (1977) The theme of gloria in Machiavelli. Renaissance Quarterly 30(4): 588-631.

Price, R. (1982) Ambizione in Machiavelli’s thought. History of Political Thought 3(3): 383445.

Putnam, R.D. (1976) The Comparative Study of Political Elites. Englewood Cliffs, N.J.: Prentice Hall, Inc.

Rawls, J. (1971) A Theory of Justice. Cambridge, Mass.: Belknap Press of Harvard University Press.

Sacksteder, W. (1989) Mutually acceptable glory as a cause of conflict. In: P. Caws (ed.) The Causes of Quarrel - Essays on Peace, War and Thomas Hobbes. Boston: Beacon Press, 97-113.

Santi, V.A. (1979) La Gloria nel Pensiero di Machiavelli. Ravenna: Longo.

Schelling, T. (1960) The Strategy of Conflict. Cambridge: Harvard University Press.

Sensen, O. (ed.) (2013) Kant on Moral Autonomy. Cambridge: Cambridge University Press. 
Slomp, G. (2000) Thomas Hobbes and the Political Philosophy of Glory. Houndmills: Macmillan Press.

Stewart, F. H. (1994) Honor. Chicago: The University of Chicago Press.

Strauss, L. (1953) The Political Philosophy of Hobbes, its Basis and its Genesis. Chicago: University of Chicago Press.

Strauss, L. (1958) Thoughts on Machiavelli. Chicago: The University of Chicago Press.

Strauss, L. (1959) What is Political Philosophy? And Other Studies. New York: The Free Press.

Tarcov, N. (1999) Locke’s Education for Liberty. Lanham, Maryland: Lexington Books.

Taylor, C. (1991) The Ethics of Authenticity. Cambridge: Harvard University Press.

Varotti, C. (1998) Gloria e Ambizione Politica nel Rinascimento. Da Petrarca a Machiavelli. Milan: Bruno Mondadori.

Walzer, M. (1983) Spheres of Justice. New York: Basic Books.

Welsh, A. (2008) What is Honor? New Haven: Yale University Press.

Williams, R.R. (2012) Tragedy, Recognition, and the Death of God: Studies in Hegel and Nietzsche. Oxford: Oxford University Press.

Wyatt-Brown, B. (1982) Southern Honor: Ethics and Behavior in the Old South. London: Oxford University Press.

Zmora, H. (2007) World without a saving grace: Glory and immortality in Machiavelli. History of Political Thought 28(3): 449-468. 